\title{
Perbandingan Prestasi Belajar Mahasiswa pada Mata Kuliah Aljabar Linier Ditinjau dari Orientasi Tujuan
}

\author{
Muhammad Irham ${ }^{1]}$, Aska Muta Yuliani ${ }^{2]}$ \\ STKIP Paracendekia NW Sumbawa \\ E-mail: ${ }^{1]}$ muhammadirham2016@gmail.com \\ ${ }^{2]}$ amy.doc.18@gmail.com
}

\begin{abstract}
Abstrak
Orientasi tujuan merupakan aspek penting dalam perkuliahan di setiap mata kuliah. Mahasiswa dengan orientasi tujuan penguasaan memandang kesuksesan sebagai suatu peningkatan kemampuan dalam diri, sedangkan mahasiswa dengan orientasi tujuan performansi memandang kesuksesan melalui perbandingan dengan orang lain. Penelitian ini bertujuan untuk membandingkan prestasi belajar mahasiswa pada mata kuliah Aljabar Linier berdasarkan orientasi tujuan. Penelitian ini merupakan penelelitian kuantitatif. Populasi dan sampel dalam penelitian ini berjumlah 19 mahasiswa. Pengumpulan data dilakukan melalui tes dan angket. Metode tes digunakan untuk mengumpulkan data prestasi matematika mahasiswa pada mata kuliah Aljabar Linier. Tes yang digunakan adalah tes berjenis uraian materi Aljabar Linier. Adapun angket digunakan untuk mengklasifikasikan mahasiswa yang memiliki orientasi tujuan penguasaan dan performansi. Teknik analisis data menggunakan uji-t pihak kanan. Uji ini dilakukan untuk mengetahui apakah mahasiswa dengan orientasi penguasaan memiliki prestasi belajar yang lebih baik dari mahasiswa yang berorientasi performansi? Atau sebaliknya. Hasil tes menunjukkan bahwa mahasiswa yang memiliki orientasi penguasaan memiliki rata-rata 83,1, sedangkan mahasiswa dengan orientasi performansi memiliki nilai rata-rata prestasi belajara sebesar 80,7. Hasil analisis data dengan uji-t pihak kanan menunjukkan bahwa $t_{\text {hitung }}=0,280364<t_{\text {tabel }}=1,740$ dengan kesimpulan bahwa tidak terdapat perbedaan prestasi belajar antara mahasiswa yang berorientasi tujuan penguasaan dengan mahasiswa yang berorientasi tujuan performansi. Ini menunjukkan bahwa orientasi tujuan mahasiswa dalam belajar pada mata kuliah Aljabar linier tidak mempunyai pengaruh siginifikan terhadap prestasi matematika pada mata kuliah Aljabar Linier.
\end{abstract}

Kata kunci: Orientasi Tujuan Penguasaan, Orientasi Tujuan Performansi, Prestasi Belajar

\section{Comparison of Student Achievement in Linear Algebra Viewed from the Orientation of Purpose}

\begin{abstract}
Goals orientation is an important aspect of learning in each subject. Students with mastery goal orientation view success as an increase in self-ability, while students with performance goal orientations view success through comparison with others. This study aims to compare student achievement in Linear Algebra courses based on goal orientation. This research is quantitative research. The population and sample in this study were 19 students. Data collection obtained from tests and questionnaires. The test method is used to collect data on student mathematics achievement in Linear Algebra. The test used is a test type description of Linear Algebra material. The questionnaire is used to classify students who have orientation in mastery and performance goals. Data analysis using the right-t-test. Data analysis techniques using the right-hand t-test. This test is conducted to determine whether students
\end{abstract}


with mastery orientation have better learning achievement than students with performance orientation? Or vice versa. The results of data analysis show that $t_{\text {hitung }}=0.280364<t_{\text {tabel }}=$ 1.740 with the conclusion that there was no difference in learning achievement between mastery goals oriented students with performance goals oriented students. This shows that the goals orientation of students in learning in Linear Algebra does not have a significant influence on mathematics achievement.

Keywords: Mastery Goal orientation, Performance Goal Orientation, Student Achievement

\section{PENDAHULUAN}

Perguruan tinggi merupakan pusat kelimuan yang di dalamnya terdapat banyak orang-orang yang ahli dalam bidang keilmuannya serta tempat pengkaderan para calon peneliti, guru dan profesi-profesi lainnya yang berkaitan dengan keilmuan. Para mahasiswa di perguruan tinggi di berikan keluasan dalam pengembangan bidang keilmuannya atau menggali secara ilmiah setiap penomena alam dan kemasyarakatan. Program studi yang fokus pada bidang pendidikan fokus pada pengembangan sumberdaya manusia yang disiapkan sebagai calon pendidik atau guru. Begitupun dengan program studi non kependidikan, fokusnya adalah keilmuan yang banyak dibutuhkan di lapangan dan masyarakat.

Mahasiswa yang kuliah di program studi pendidikan matematika atau matematika murni tidak selamanya akan menjadi guru atau dosen matematika, atau pekerjaan yang ada hubungan secara langsung dengan matematika. Akan tetapi, program studi pendidikan matematika atau matematika murni mengajarkan mahasiswa untuk berpikir dan bertindak secara analitis dan logis. Adapun kemampuan berpikir logis dan rasional akan memudahkan mahasiswa dalam mengambil keputusan dari sekian banyak peluang dengan pertimbanganpertimbangan yang matang. Sehingga bisa dikatakan bahwa kemampuan berpikir secara matematis merupakan kompetensi yang sangat dibutuhkan untuk bisa ikut mengambil andil dalam persaingan global dan kompetisi modern saat ini.
Prestasi yang mampu diperoleh selama dalam proses belajar di perguruan tinggi merupakan hal yang penting bagi mahasiswa. Oleh karena itu motivasi berprestasi sangat diperlukan bagi mahasiswa untuk terus meningkatkan capaian akademiknya. Salah satu ciri mencolok dari motivasi berprestasi adalah tujuan pencapaian yang ditargetkan oleh mahasiswa tentang capaian akademiknya. Tujuan pencapaian yang ditagertkan oleh mahasiswa memiliki efek sosial yang kuat, karena bisa membuat mahasiswa bekerjasaman atau melawan orang lain untuk mencapai tujuan yang sudah mereka tetapkan (Poortvliet \& Darnon, 2010).

Selama masa kuliah, mahasiswa tidak hanya sedang berada dalam proses kematangan berpikir tetapi juga dalam proses kematangan diri yang ditunjukkan melalui konsep diri selama kuliah. Konsep diri yang positif akan membantu mahasiswa terhindar dari masalah-masalah akademik ataupun non akademik. Marsh (dalam Hadi dan Budiningsih, 2014) menyebutkan bahwa seseorang yang mempunyai konsep diri positif akan menjadi individu yang mampu memandang dirinya secara positif, berani mencoba dan mengambil resiko, selalu optimis, percaya diri, dan antusias menetapkan arah dan tujuan hidup. Adapun seseorang yang mempunyai konsep diri negatif akan meyakini dan memandang dirinya lemah, tidak dapat berbuat, tidak kompeten, gagal, tidak menarik, tidak disukai dan kehilangan daya tarik terhadap hidup. 
Konsep diri mahasiswa mempunyai hubungan erat dengan tujuan yang ditetapkan mahasiswa selama kuliah. Mahasiswa yang memiliki konsep diri yang positif memiliki tujuan yang visioner, memiliki motivasi untuk berprestasi dan senantiasa mampu berpikir positif terhadap setiap masalah yang dihadapi. Adapun mahasiswa yang memiliki konsep diri negatif akan kesulitan dalam menentukan tujuan dikarenakan sikap pesimis dan pandangannya terhadap masalah yang seakan tidak bisa terselesaikan.

Dalam proses belajar, mahasiswa memiliki perbedaan pandangan terhadap keberhasilan dalam mata kuliah yang sedang ditempuh. Beberapa mahasiswa memandang bahwa nilai merupakan tolok ukur keberhasilannya dalam mata kuliah tersebut. Namun, tidak sedikit pula mahasiswa yang memandang bahwa penguasaannya terhadap mata kuliah tersebut merupakan tolok ukur keberhasilan. Dua perbedaan tersebut kemudian dapat dijelaskan sebagai orientasi penguasaan (mastery goal) dan orientasi performansi (performance goal) (Puspitasari, et al. 2013)

Mahasiswa dengan orientasi tujuan penguasaan memahami sukses dalam standar absolut atau berdasarkan atas referensi diri. Hal ini menyebabkan mahasiswa dengan orientasi tujuan penguasaan akan merasa sukses jika dirinya mampu berkembang lebih baik dari sebelumnya. Adapun mahasiswa dengan orientasi performansi memiliki perbandingan sukses eksternal atau membandingkan diri dengan orang lain. Dalam prakteknya, mahasiswa dengan orientasi performansi akan merasa dirinya sukses jika teman sejawatnya memperoleh hasil yang lebih rendah dari dirinya.

Orientasi tujuan memiliki hubungan positif dengan penetapan tujuan dan perencanaan, membuat catatan dan pemantauan, berlatih, mengingat dan mencari bantuan (hubungan) sosial (Alraggad, F., et al. 2014). Pemahaman tentang konsekuensi sosial dari orientasi tujuan penguasaan dan preformansi akan berkontribusi pada pemahaman yang lebih besar tentang tujuan pencapaian secara keseluruhan (Poortvliet \& Darnon, 2010).

Artinya, orientasi tujuan menjadikan mahasiswa untuk mampu menetapkan tujuan yang ingin dicapai dibarengi dengan perencanaan yang matang, membuat catatan serta melakukan pemantuan untuk setiap tahap mencapai tujuan, memaksimalkan latihan, menghafal atau mengingat tahapan yang harus dilakukan dan mencari bantuan sosial jika terdapat kendala atau kesulitan untuk mencapai tujuan yang telah ditetapkan. Dengan demikian, orientasi tujuan seyogyanya mampu menjadikan mahasiswa menjadi lebih memperhatikan apa yang akan dilakukan dalam bentuk perencanaan, apa yang sedang dilakukan sebagai wujud monitoring serta lakukan evaluasi terhadap apa yang telah dilakukan. Semua tahapan tersebut adalah untuk mencapai tujuan yang telah ditetapkan.

Penelitian Wahyuningtyas (2013) berkesimpulan bahwa terdapat hubungan positif yang signifikan antara orientasi tujuan dengan prestasi belajar. Kenaikan variabel orientasi tujuan akan menyebabkan variabel prestasi belajar. Begitupun saat terjadi penurunan pada variabel orientasi tujuan menyebabkan penurunan pada variabel prestasi belajar.

Konsep orientasi tujuan pada dasarnya berasal dari teori sosial kognitif tentang motivasi berprestasi yang spesifik pada tujuan yang berhubungan langsung dengan perilaku berprestasi (Maehr \& Zusho, dalam Geitz, G., et al. 2015). Perbedaan orientasi tujuan mahasiswa mengakibatkan berbedanya pandangan mahasiswa tentang belajar. Elliot dan McGregor (dalam Geitz, G., et al. 2015) juga menemukan bahwa orientasi tujuan menyebabkan perbedaan dalam pola-pola perilakukan belajar. Mahasiswa yang orientasinya penguasaan lebih menonjol dengan perilaku belajar yang aktif, seperti keterlibatan dalam menyelesaikan masalah, menyukai tantangan dan mendalami materi. 
Menurut Keys, at al. (2012) orientasi tujuan juga dapat dibentuk oleh guru dan lingkungan belajar. Pembentukan orientasi tujuan oleh guru dapat dilakukan selama dalam proses pembelajaran melalui nilainilai dan pandangan tentang apa yang siswa butuhkan untuk menghadapi tantangan ke dapan. Guru juga bisa mengarahkan siswa untuk menetapkan tujuan, merencanakan tahapan mencapai rencana, serta membantu untuk mencapai tujuan yang telat ditentukan. Adapun lingkungan belajar sangat berpengaruh terhadap mental dan motivasi belajar siswa yang juga mempengaruhi orientasi tujuan siswa.

Penelitian tentang orientasi tujuan penguasaan salah satunya berkesimpulan bahwa orientasi tujuan penguasaan memiliki hubungan positif dengan berpikir positif dan efikasi diri pada mata pelajara matematika. Penelitian Ulfah \& Listiara (2017) menunjukkan bahwa kooefisien korelasi antara orientasi tujuan penguasaan dan efikasi diri akademik dalam pelajaran matematika sebesar 0,496 dengan $\mathrm{p}=$ 0,000. Hasil ini menunjukkan bahwa korelasi antar variabel adalah korelasi positif dan signifikan. Ini artinya, semakin tinggi orientasi tujuan penguasaan semakin tinggi pula efikasi diri akademik siswa pada pembelajaran matematika. Hasil uji lanjut dengan menggunakan uji regresi menunjukkan bahwa pengaruh orientasi tujuan penguasaan pada efikasi diri akademik siswa adalah sebesar 24,6\%. Hasil penelitian Keys, et al. (2012) juga berkesimpulan bahwa dari beberapa variabel yang digunakan untuk memprediksi prestasi belajar, hanya orientasi tujuan yang secara konsisten mampu memprediksi prestasi belajar matematika siswa. Di mana siswa dengan orientasi tujuan penguasaan tinggi mengalami peningkatan prestasi belajar yang tinggi jika dibandingkan dengan sampel yang lain.

Ames (dalam Dierendonck dan Gaast, 2013) menjelaskan bahwa individu yang memiliki orientasi tujuan penguasaan selalu mengorientasikan dirinya pada keterampilan baru, mencoba memahami pekerjaannya, meningkatkan level kompetensinya atau mencapai tingkat penguasaan berdasarkan standar penguasaan dirinya sendiri. Orientasi tujuan juga dipercaya mampu membuat perbedaan pada kerangka konseptual kognitif seseorang untuk bagaimana pendekatan, interpretasi dan respon terhadap situasi prestasi. Church, Rawsthorne dan Elliot (dalam Dierendonck dan Gaast, 2013) juga menjelaskan bahwa orientasi tujuan penguasaan individu identik dengan keinginan berprestasi yang tinggi, motivasi intrinsik dan ketertarikan terhadap tugas atau tantangan. Bahkan, individu yang memiliki orientasi tujuan penguasaan menganggap bahwa setiap usaha yang dilakukan merupakan salah satu indikasi keberhasilan dan prestasi. Hal ini dikarenakan orang yang berorientasi pengusaan cenderung memandang upaya maksimal yang dilakukan adalah capaian yang diinginkan oleh dirinya sendiri. Akan tetapi, orientasi tujuan penguasaan memiliki saling ketergangungan yang rendah dengan orang lain, karena mereka akan mecapai tujuan mereka saat kinerja individunya meningkat dan tidak berhubungan dengnan kinerja orang lain (Poortvliet \& Darnon, 2010). Disisi lain, orientasi tujuan penguasaan memungkinkan untuk terjalinnya rasa saling ketergantungan yang positif yang dapat meningkatkan kesediaan individu dalam pertukaran potensi yang bertujuan untuk peningkatan kompetensi diri.

Berbanding terbalik dengan individu yang berorientasi performansi, di mana menurut Dweck dan Legget; Yperen dan Janssen (dalam Dierendonck dan Gaast, 2013), individu dengan orientasi performansi berpandangan bahwa bekerja keras dalam mengerjakan sesuatu (termasuk dalam belajar) adalah tanda lemahnya kemampuan yang dimiliki. Terkadang inilah yang membuat mereka tidak yakin dengan kompetensi yang dimilikinya untuk memenuhi standar kompetitif. Inilah yang menjadikan 
individu dengan orientasi tujuan performansi seringkali mengevaluasi kinerja dirinya berdasarkan perbandingan sosial. Dari sisi rasa ketergantungan dengan orang lain, orientasi tujuan performansi memiliki rasa saling ketergantungan negatif dengan orang lain yang akan mengakibatkan kurangnya kemauan untuk berkoordinasi untuk pertukaran potensi karena mereka akan mencapai tujuannya ketika mereka mampu mengungguli orang lain (Poortvliet \& Darnon, 2010).

Mahasiswa dengan orientasi tujuan performansi juga lebih menonjol pada sikap yang pasif dalam menunjukkan perilaku belajar. Bahkan, Variansyah \& Listiara (2017) dalam penelitiannya berkesimpulan bahwa orientasi tujuan performansi memiliki korelasi positif antaran orientasi tujuan performansi dengan tingkat kecemasan siswa. Hasil uji koefisien korelasi (R) antara orientasi tujuan performansi dan kecemasan akademik sebesar 0,588 dengan signifikansi 0,000 (p $<0,001$ ). Koefisien korelasi yang memiliki nilai positif memberikan kesimpulan bahwa arah hubungan kedua variabel adalah positif, di mana siswa yang memiliki orientasi tujuan performansi rendah akan memiliki kecemasan akademik yang rendah pula. Sebaliknya, siswa yang memiliki orientasi tujuan performansi tinggi akan memiliki kecemasan akademik tinggi. Hasil ini dikuatkan lagi dengan uji pengaruh antara orientasi tujuan performansi dengan kecemasan akademik di mana disimpulkan bahwa orientasi tujuan performansi berkontribusi sebesar $35 \%$ terhadap kecemasan akademik.

Berbedanya pandangan mahasiswa tentang belajar yang disebabkan karena berbedanya orientasi, diprediksikan juga akan membuat perbedaan prestasi belajar mahasiswa. Kemungkinan yang mungkin terjadi adalah mahasiswa dengan orientasi penguasaan memiliki prestasi belajar yang lebih baik dari mahasiswa dengan orientasi performansi atau mahasiswa dengan orientasi performansi lebih baik dari mahasiswa dengan orientasi penguasaan.
Atau kemungkinan mahasiswa dengan kedua orientasi tersebut tidak memiliki perbedaan dalam hal prestasi belajar.

Prestasi belajar secara umum berkaitan engan kompetensi dalam bidang akademik dan pengetahuan. Di mana dalam logika sederhana atau persepsi masyarakat awam bahwa pengetahuan yang diperoleh selama belajar dan kompetensi akademik berpengaruh pada kesuksesan di dalam karir. Subyabrata (dalam Indrawati, 2013) mendefinisikan prestasi belajar sebagai buah dari penilaian yang disimbolkan dengan angka atau dengan lambang yang intinya adalah tentang kemajuan atua hasil belajar dalam suatu masa periode tertentu. Sunarya (dalam Indrawati, 2013) menyatakan bahwa prestasi belajar juga diidentikkan sebagai suatu bentuk perubahan tingkah laku baik dalam ranah kognitif, afektif ataupun psikomotor yang menjadi tolok ukur keberhasilan siswa.

Pada intinya, prestasi belajar adalah capaian akhir dari suatu proses belajar yang telah dilalui baik melalui tugas ataupun materi yang dipelajari, dipahami dan diimplementasi dalam jangka waktu tertentu yang berwujud pengetahuan, sikap ataupun keterampilan yang disimbolkan dengan angka atau huruf dan dapat dikategorisasikan. Pada penelitian ini, prestasi yang dimaksudkan adalah hasil dari tes yang masuk dalam ketegori kognitif.

Oleh karena itu, prestasi belajar dalam penelitian ini diukur melalui tes atau uji kompetensia pada mata kuliah Aljabar Linier. Aljabar Linier merupakan salah satu mata kuliah wajib di program studi Pendidikan Matematika dengan bobot 3 (tiga) sks. Aljabar Linier merupakan salah satu cabang matematika yang mempelajari tentang persamaan linier dengan penyelesaiannya, vektor dan transformasi linier. Aljabar Linier juga berkaitan erat dengan matriks dengan operasinya. Tujuan dari mata kuliah ini adalah agar mahasiswa mampu memahami konsep linier serta pengaplikasiannya dalam kehidupan nyata. 
Mata kuliah Aljabar Linier diharapkan mampu menjadikan mahasiswa berpikir logis, kritis, inovatif dan sistematis baik dalam konteks teori ataupun dalam konteks implementasi dan pengembangan. Karakter kemandirian, mampu bekerjasama, dan disiplin juga menjadi bagian karakterisasi selama perkuliahan berlangsung.

Terdapat beberapa penelitian yang menyatakan bahwa terdapat hubungan antara orientasi tujuan dengan kompetensi akademik atau prestasi belajar seseorang, diantaranya:

a. Penelitian Gul, F. \& Shehzad S. (2012) dengan judul "Relationship between Metacognition, Goal Orientation and Academic Achievement" menggunakan teknik pengumpulan data survey dan teknik analisis data menggunakan uji korelasi. Kesimpulannya adalah terdapat hubungan antara metakognisi, orientasi tujuan dan prestasi akademik tetapi termasuk dalam kategori sedang dengan $r=0,44$. Korelasi yang kuat justru terdapat pada hubungan antara orientasi tujuan penguasaan dengan metakognisi dengan $r=0,53$.

b. Penelitian Chen \& Wong (2014) dengan judul "Chinese mindset: theories of intelligence, goal orientation and academic achievement in Hong Kong students" bertujuan untuk memeriksa hubungan antara teori kecerdasan dengan orientasi tujuan. Dengan menggunakan metode survey terhadap 418 mahasiswa diperoleh kesimpulan bahwa mahasiswa percaya bahwa kecerdasan berkontribusi terhadap prestasi akademiknya dengan difasilitasi oleh orientasi tujuan baik orientasi tujuan penguasaan atau orientasi tujuan performansi.

c. Penelitian Ulfah dan Listiara (2017) dengan judul "Hubungan Orientasi Tujuan Penguasaan dan Berpikir Positif Dengan Efikasi Diri Akademik dalam Pelajaran Matematika pada Siswa SMA" bertujuan untuk mengetahui hubungan orientasi tujuan penguasaan dan berpikir positif dengan efikasi diri akademik dalam pelajaran matematika pada siswa SMA. Hasilnya menunjukkan bahwa terdapat hubungan positif yang signifikan antara orientasi tujuan penguasaan dengan efikasi diri akademik dalam pelajaran matematika dengan $\mathrm{r}=$ 0,496 .

d. Penelitian Dierendonck dan Gaast (2013) dengan judul "Goal Orientation, Academic Competence and Early Career Success" bertujuan untuk fokus pada keberhasilan karir yang dipengaruhi oleh kompetensi akademik. Penelitian ini berkesimpulan bahwa dengan sampel yang digunakan menunjukkan orientasi tujuan seseorang sangat berpengaruh terhadap kesuksesan baik secara subjektif maupun objektif. Penelitian ini juga berkesimpulan bahwa orientasi tujuan penguasaan lebih bermanfaat daripada orientasi tujuan performansi. Dalam kasus tertentu kedua orientasi tujuan sama-sama memiliki pengaruh positif terhadap kompetensi akademik. Penelitian ini juga merekomendasikan bahwa orientasi tujuan pada individu sangat relevan untuk dijadikan sebagai prediktor tambahan kesuksesan subjektif di atas kompetensi akademi.

Berdasarkan paparan di atas, disusun pertanyaan penelitian "apakah terdapat perbedaan prestasi belajar mahasiswa dengan orientasi penguasaan dengan mahasiswa dengan orintasi performasi pada mata kuliah Aljabar Linier?"

\section{METODE}

Penelitian ini merupakan penelitian kuantitatif, yaitu penelitian yang lebih cocok digunakan untuk meneliti jika permasalahan sudah jelas, datanya teramati dan terukur, peneliti bermaksud menguji hipotesis dan membuat generalisasi (Supardi, 2013: 20). Populasi sekaligus sampel dalam penelitian ini adalah seluruh mahasiswa yang menempuh mata kuliah 
Aljabar Linier, yaitu sebanyak 19 mahasiswa. Pengumpulan data dilakukan dengan menggunakan metode tes dan angket. Metode tes digunakan untuk mengumpulkan data prestasi matematika mahasiswa pada mata kuliah Aljabar Linier, sedangkan metode angket digunakan untuk mengumpulkan dan mengklasifikasikan orientasi tujuan mahasiswa.

Angket yang digunakan terdiri dari 33 pernyataan yang dijabarkan berdasarkan 8 dimensi orientasi tujuan. Dimensi pertama pada angket adalah tentang definisi kesuksesan. Indikator definisi kesuksesan pada orientasi tujuan penguasaan adalah bagaimana mahasiswa memfokuskan diri pada penguasaan/ peningakatan/ kreativitas/ melakukan inovasi. Adapun pada orientasi performansi yang menjadi indikatornya adalah bagaimana mahasiswa mencapai kualitas tertinggi dan penampilan terbaik.

Dimensi kedua adalah dimensi penempatan nilai. Indikator orientasi tujuan penguasaan pada dimensi ini adalah lebih menghargai usaha atau proses pembelajaran. sedangkan pada indokator orientasi tujuan performansi adalah lebih menghargai pada pencapaian kemampuan yang tinggi. Dimensi yang ketiga adalah dimensi alasan untuk berusaha. Dalam dimensi ini, orientasi tujuan penguasaan, alasan untuk berusaha muncul dalam diri (intrinsik) dan ingin belajar sesuatu yang baru. Sedangkan untuk orientasi tujuan performansi, alasan untuk berusaha lebih kepada untuk menunjukkan diri kepada yang lain.

Dimensi orientasi tujuan yang keempat adalah kriteria evaluasi. Pada dimensi ini, orientasi tujuan penguasaan memiliki kriteria untuk mengevaluasi sesuai kerangka kemajuan yang telah dibuat dengan melihat progres dirinya. Adapun untuk orientasi tujuan performansi, kriteria evaluasinya adalah melakukan evaluasi sesuai dengan penilaian orang lain atau membandingkan dengan orang lain.
Cara memandang suatu kesalahan juga menjadi dimensi kelima dalam orientasi tujuan. Orientasi tujuan penguasaan memandang suatu kesalahan sebagai bagian dari pembelajaran dan informasi yang berguna untuk memperbaiki diri. Sedangkan orientasi tujuan performansi memandangnya sebagai suatu kegagalan dan bukti kurangnya kemampuan. Dimensi keenam adalah tentang kepuasan. Dalam dimensi ini, orientasi tujuan penguasaan menunjukkan kepuasannya dengan merasa puas dengan berusaha keras dan melakukan tugas-tugas yang menantang. Untuk orientasi tujuan performansi akan merasa puas jika mampu menunjukkan diri lebih unggul dari yang lainnya.

Dimensi ketujuh adalah tentang orientasi dosen terhadap dirinya. Indikator pada orientasi penguasaan adalah dosen berorientasi pada proses belajar mahasiswanya atau bagaimana mahasiswa belajar. Adapun pada orientasi tujuan performansi menganggap bahwa dosen berorientasi pada bagaimana mahasiswa menunjukkan kinerjanya. Adapun dimensi terakhir adalah dimensi pusat perhatian. Pada dimensi ini orientasi tujuan penguasaan menunjukkan pusat perhatian dengan cara memfokuskan diri pada proses pembelajaran atau melakukan pembelajaran yang bermakna. Adapun pada orientasi tujuan performansi, pusat perhatian ditunjukkan dengan memfokuskan diri pada kinerja yang baik dengan memperhatikan kinerja orang lain.

Berdasarkan 8 dimensi tersebut, orientasi tujuan penguasaan fokus pada capaian diri sendiri dalam belajar. Capaian diukur melalui tingkat penguasaan atau pemahaman pada mata kuliah atau materi yang dipelajari. Kesalahan yang dilakukan juga dipandang sebagai bagian dari pembelajaran dan informasi yang berguna untuk memperbaiki diri.

Adapun orientasi tujuan performasi fokus pada capaian hasil diri sendiri dan dibandingkan dengan hasil capaian orang lain. Kepuasaannya ditunjukkan dengan 
dengan menonjolkan diri lebih unggul dibandingkan dengan orang lain. Kesalahan juga dianggap sebagai kegagalan dan bukti kurangnya kemampuan.

Tes yang diberikan adalah tes uraian yang terdiri dari 5 soal. Soal-soal diambil dari materi mata kuliah Aljabar Linier dan dijadikan untuk mengukur prestasi mahasiswa pada mata kuliah Aljabar Linier. Tes ini dinilai dengan menggunakan rubrik penskoran.

Analisis data dilakukan dengan menggunakan uji beda rata-rata atau independent sample t-test. Uji beda ratarata dilakukan untuk mengetahui apakah terdapat perbedaan prestasi belajar mahasiswa yang berorientasi tujuan penguasan dengan mahasiswa yang beorientasi tujuan performansi. Uji ini dilakukan juga sekaligus untuk mengetahui apakah mahasiswa dengan orientasi penguasaan memiliki prestasi belajar yang lebih baik dari mahasiswa yang berorientasi performansi? Atau sebaliknya.

Adapun tahapan uji beda rata-rata dengan independent sample t-test adalah sebagai berikut.

\section{a. Uji Normalitas}

Uji normalitas dilakukan untuk mengetahui apakah data yang diperoleh berasal dari populasi yang berdistribusi normal atau tidak. Uji normalitas dalam penelitian ini menggunakan uji Kolmogorov-Smirnov. Uji normalitas pada penelitian ini menggunakan taraf signifikansi $5 \%$. Adapun hipotesis yang digunakan adalah:

$\mathrm{H}_{0} \quad$ : Data berdistribusi normal

$\mathrm{H}_{1} \quad$ : Data berdistribusi tidak normal

Kriteria penerimaan:

Terima $\mathrm{H}_{0}$ jika sig. $\geq 5 \%$. Jika berlaku sebaliknya, $\mathrm{H}_{0}$ ditolak.

\section{b. Uji Homogenitas}

Uji homogenitas dilakukan untuk mengetahui apakah data yang diperoleh diambil dari varians yang homogen atau tidak. Uji homogentitas menggunakan uji Lavene dengan taraf signifikansi 5\%. adalah:
$\mathrm{H}_{0} \quad$ : Data mahasiswa berorientasi tujuan penguasaan dan performansi memiliki varians yang homogen.

$\mathrm{H}_{1}$ : Data mahasiswa berorientasi tujuan penguasaan dan performansi memiliki varians yang tidak homogen.

Kriteria penerimaan:

Terima $\mathrm{H}_{0}$ jika sig. $\geq 5 \%$. Jika berlaku sebaliknya, $\mathrm{H}_{0}$ ditolak.

\section{c. Uji Beda Rata-rata}

Uji beda rata-rata dilakukan dengan menggunakan statistik uji $\mathrm{t}$ pihak kanan yang rumusnya sebagai berikut.

$$
t=\frac{\bar{x}_{1}-\bar{x}_{2}}{\sqrt{\frac{\left(n_{1}-1\right) s_{1}^{2}+\left(n_{2}-1\right) s_{2}^{2}}{n_{1}+n_{2}-2}\left(\frac{1}{n_{1}}+\frac{1}{n_{2}}\right)}}
$$

dengan,

$\bar{x}_{1}=$ Rata-rata prestasi belajar mahasiswa beorientasi penguasaan

$\bar{x}_{2}=$ Rata-rata prestasi belajar mahasiswa beorientasi performansi

$s_{1}^{2}=$ Varians prestasi belajar mahasiswa beorientasi penguasaan

$s_{2}^{2}=$ Varians prestasi belajar mahasiswa beorientasi performansi

$n_{1}=$ Jumlah mahasiswa yang berorientasi penguasaan

$n_{2}=$ Jumlah mahasiswa yang berorientasi performansi

Hipotesis statistiknya adalah sebagai berikut.

$\mathrm{H}_{0}$

$$
\begin{aligned}
& : \mu_{1} \leq \mu_{2} \text { (Rata-rata } \\
& \text { prestasi belajar mahasiswa } \\
& \text { beorientasi penguasaan } \\
& \text { lebih rendah atau sama } \\
& \text { dengan rata-rata prestasi } \\
& \text { belajar mahasiswa } \\
& \text { beorientasi performansi) } \\
& : \mu_{1}>\mu_{2} \text { (Rata-rata } \\
& \text { prestasi belajar } \\
& \text { mahasiswa beorientasi } \\
& \text { penguasaan lebih besar } \\
& \text { dari rata-rata prestasi } \\
& \text { belajar mahasiswa } \\
& \text { beorientasi performansi) }
\end{aligned}
$$$$
\begin{array}{rrr}
\mathrm{H}_{1} & \mu_{1}>\mu_{2} & \text { (Rata-rata } \\
& \text { prestasi } & \text { belajar }
\end{array}
$$

Kriteria Penerimaan:

$\mathrm{H}_{0}$ diterima jika $t_{\text {hitung }}<t_{\text {tabel }}$ dengan peluang taraf signifikan $5 \%$ diperoleh 
derajat kebebasan $n_{1}+n_{2}-2$. Jika berlaku sebaliknya, maka $\mathrm{H}_{0}$ ditolak.

\section{HASIL DAN PEMBAHASAN \\ 3.1 Hasil}

\subsubsection{Hasil Angket Orientasi Tujuan}

Hasil verifikasi angket orientasi tujuan menunjukkan hasil seperti gambar berikut.

\section{Orientasi Tujuan}

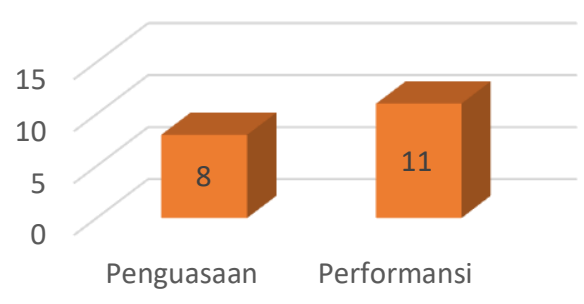

Diagram 1. Hasil Angket Orientasi Tujuan

Berdasarkan gambar di atas, mahasiswa dengan orientasi tujuan penguasaan adalah sebanyak 8 mahasiswa. Adapun untuk mahasiswa yang memiliki orientasi tujuan performansi adalah sebanyak 11 mahasiswa. Berikutnya data tersebut digunakan untuk mengklasifikan hasil tes mata kuliah Aljabar Linier berdasarkan orientasi tujuannya, dan selanjutnya dilakukan uji beda rata-rata antara hasil tes mahasiswa dengan orientasi tujuan penguasaan dengan hasil tes mahasiswa dengan orientasi performansi.

Hasil angket menunjukkan bahwa semua mahasiswa Pendidikan Matematika memiliki dua orientasi tujuan sekaligus. Adapun klasifikasi orientasi tujuan mahasiswa didasarkan pada kecondongan dari nilai angket yang diperoleh. Mahasiswa yang lebih dominan hasil angketnya menunjukkan beroeintasi tujuan penguasaan, diklasifikasikan sebagai mahasiswa dengan orientasi tujuan penguasaan. Adapun mahasiswa yang lebih dominan hasil angketnya pada orientasi tujuan performansi, diklasifikasian sebagai mahasiswa yang berorientasi tujuan performansi.

\subsubsection{Hasil Uji Statistik Deskriptif}

Hasil uji statistik deskriptif prestasi belajar mahasiswa berdasarkan orientasi tujuannya adalah sebagaimana Tabel 1 .

Tabel 1. Hasil Statistik Deskriptif Prestasi Belajar Mahasiwa Berdasarkan Orientasi Tujuan

\begin{tabular}{|c|c|c|c|c|c|}
\hline Nilai & $\begin{array}{c}\text { Mea } \\
\text { n }\end{array}$ & $\begin{array}{c}\text { Mod } \\
\text { us }\end{array}$ & $\begin{array}{c}\text { Mi } \\
\text { n }\end{array}$ & $\begin{array}{c}\text { Ma } \\
\mathbf{x}\end{array}$ & SD \\
\hline Orientasi & & & & & \\
\hline Penguasa & & & & & 12,53 \\
\hline $\begin{array}{c}\mathrm{n} \\
\text { Orientasi }\end{array}$ & 83,1 & 95 & 65 & 95 & 4 \\
\hline $\begin{array}{l}\text { Performa } \\
\text { nsi }\end{array}$ & 80,7 & 80 & 45 & 95 & 14,23 \\
\hline
\end{tabular}

Berdasarkan Tabel 1. di atas diperoleh informasi bahwa rata-rata prestasi belajar mahasiswa yang memiliki orientasi penguasaan lebih besar dari rata-rata prestasi belajar mahasiswa yang berorientasi performansi. Rata-rata prestasi belajar mahasiswa yang berorientasi tujuan penguasaan adalah 83,1 sedangkan mahasiswa yang berorientasi tujuan performansi adalah 80,7. Hasil tersebut menunjukkan bahwa terdapat selisih sebesar 2,4 antara prestasi belajar mahasiswa berorientasi tujuan penguasaan dengan mahasiswa berorientasi tujuan performansi. Selisih tersebut tergolong sangat kecil untuk disimpulkan terdapat perbedaan prestasi antara mahasiswa yang berorientasi tujuan penguasaan dengan mahasiswa yang berorientasi performansi.

Mahasiswa yang berorientasi penguasaan memiliki nilai tertinggi 95 dan nilai terendah 65. Adapun mahasiswa yang berorientasi performansi memiliki nilai tertinggi 95 dan nilai terendah 45 .

\subsubsection{Hasil Uji Beda Rata-rata}

\section{a. Hasil Uji Normalitas}

Uji normalitas dilakukan dengan berbantuan SPSS 16. Hasil uji normalitas dapat dilihat sebagaimana Tabel 2. 
Tabel 2. Hasil Uji Normalitas

\begin{tabular}{lccc}
\hline \multicolumn{4}{c}{ Kolmogorov-Smirnov $^{\mathrm{a}}$} \\
\hline & Statistic & Df & Sig. \\
\hline Penguasaan & .069 & 17 & $.200^{*}$ \\
_Performan & & & \\
Si \\
a. Lilliefors Significance Correction \\
*. This is a lower bound of the true \\
significance \\
\hline
\end{tabular}

Tabel 2. menunjukkan bahwa data prestasi belajar mahasiswa dengan orientasi tujuan penguasaan dan performansi memberikan hasil sig. $=0.200 \geq$ taraf signifikansi 0,05 . Ini artinya $\mathrm{H}_{0}$ diterima, sehingga bisa disimpulkan bahwa prestasi belajar mahasiswa pada mata kuliah Aljabar Linier berasal dari distribusi normal.

\section{b. Hasil Uji Homogenitas}

Uji homogenitas juga dilakukan dengan berbantuan SPSS 16. Adapun hasil uji homogenitas adalah sebagaimana Tabel 3.

Tabel 3. Hasil Uji Homogentitas

\begin{tabular}{clcc}
\hline & & \multicolumn{2}{c}{$\begin{array}{c}\text { Levene's } \\
\text { Test for } \\
\text { Equality of } \\
\text { Variances }\end{array}$} \\
\cline { 3 - 4 } & & F & Sig. \\
\hline & Equal & & \\
Prestasi & Variances & 3.537 & .065 \\
Belajar & Assumed & & \\
Mahasiswa & Equal & & \\
& Variances & & \\
& not & \\
& Assumed & \\
\hline
\end{tabular}

Hasil uji homogenitas di atas menunjukkan bahwa nilai sig. $=0.065 \geq$ taraf signifikansi 0,05. Artinya $\mathrm{H}_{0}$ diterima, sehingga disimpulkan bahwa data prestasi belajar mahasiswa yang berorientasi tujuan penguasaan dan performasi memiliki varians yang sama atau homogen.

\section{c. Hasil Uji Beda Rata-rata}

Hasil uji beda rata-rata prestasi belajar mahasiswa yang berorientasi tujuan penguasaan dan mahasiswa yang berorientasi performansi adalah sebagai berikut;

$$
\begin{aligned}
& t=\frac{\bar{x}_{1}-\bar{x}_{2}}{\sqrt{\frac{\left(n_{1}-1\right) s_{1}^{2}+\left(n_{2}-1\right) s_{2}^{2}}{n_{1}+n_{2}-2}\left(\frac{1}{n_{1}}+\frac{1}{n_{2}}\right)}} \\
& t \\
& =\frac{83,111-80,7}{\sqrt{\frac{(9-1) 157,11+(10-1) 202,68}{9+10-2}\left(\frac{1}{9}+\frac{1}{10}\right)}} \\
& =0,280364
\end{aligned}
$$

Berdasarkan hasil pengujian di atas diperolejh nilai $t_{\text {hitung }}=0,280364$. Adapun nilai $t_{\text {tabel }}$ untuk dk $=17$ adalah 1,740. Dengan demikian disimpulkan bahwa $\quad t_{\text {hitung }}=0,280364<t_{\text {tabel }}=$ 1,740 yang artinya $\mathrm{H}_{0}$ diterima sehingga bisa disimpulkan bahwa tidak terdapat perbedaan prestasi belajar mahasiswa yang berorientasi tujuan penguasan dengan mahasiswa yang berorientasi performansi. Hal ini juga menunjukkan bahwa perbedaan orientasi tujuan mahasiswa tidak mengakibatkan berbedanya prestasi belajar mahasiswa pada mata kuliah Aljabar Linier.

\subsection{Pembahasan}

Hasil uji beda rata-rata prestasi belajar mahasiswa pada mata kuliah Aljabar Linier tidak menunjukan adanya perbedaan rata-rata yang signifikan antara mahasiswa yang memiliki orientasi penguasaan dengan mahasiswa yang memiliki orientasi performansi. Adapun jika dilihat dari nilai rata-rata prestasi belajar pada masing-masing orientasi mahasiswa terdapat perbedaan yang tidak terlalu besar. Mahasiswa yang memiliki orientasi penguasaan memiliki rata-rata 83,1, sedangkan mahasiswa dengan orientasi performansi memiliki nilai ratarata prestasi belajara sebesar 80,7 . Terdapat rentang 2,4 antara rata-rata prestasi belajar mahasiswa yang berorientasi penguasaan dan mahasiswa yang memiliki orientasi performansi.

Hasil uji beda rata-rata prestasi belajar mahasiswa dengan orientasi tujuan penguasaan dan orientasi tujuan 
performansi yang menunjukkan bahwa tidak adanya perbedaan signifikan antara keduanya juga bisa menyimpulkan bahwa tidak adanya pengaruh yang signifikan dari perbedaan orientasi terhadap prestasi belajar. Hasil tersebut sejalan dengan hasil penelitian Gul dan Shehzad (2012) yang menyatakan bahwa terdapat hubungan yang lemah antara orientasi tujuan dengan prestasi belajar. Sehingga bisa dikatakan bahwa orientasi tujuan tidak mempengaruhi prestasi akademik mahasiswa. Mahasiswa hanya fokus menunjukkan kinerjanya yang baik pada saat ujian atau karena mahasiswa hanya ingin memiliki kemapuan akademik yang sama dengan rekan-rekannya. Perbedaan hasil penelitian tentang pengaruh orientasi tujuan terhadap perastasi belajar pada akhirnya sebagaimana yang di katakan oleh Keys, et al. (2012) bahwa hubungan positif antara orientasi tujuan dengan prestasi akademik adalah hal yang masih menjadi perdebatan.

Nilai terendah pada mahasiswa dengan orientasi tujuan penguasaan adalah 65, sedangkan bagi mahasiswa orientasi tujuan performansi adalah 45. Ini menunjukkan bahwa bagi sebagian mahasiswa, Aljabar Linier adalah salah satu mata kuliah yang memiliki tingkat kesulitan tersendiri. Diantara kesulitankesulitan yang menjadi kendala mahasiswa menurut Ferryansyah, et al. (2018) dalam menyelesaikan masalah Aljabar Linier adalah, (1) Konsep yang abstrak; (2) daerah pengaplikasiannya tidak biasa bagi mahasiswa; (3) mahasiswa belum memahami metode pembuktian dan aksiomatik; (4) konsep dasar Aljabar Linier tidak ditampilkan secara geometris; (5) mahasiswa hanya menghapal konsep tanpa memahami dengan benar; (6) mahasiswa gagal dalam abstraksi suatu konsep abstrak; (7) mahasiswa gagal dalam konsepsi definisi; (8) mahasiswa gagal menafsirkan verbal; dan (9) mahasiswa tidak mampu pada level kesiapan. Di sisi lain, bagi mahasiswa yang memiliki konsep abstraksi, memahami dengan baik konsep pembuktian, dan memiliki kemampuan- kemampuan lain yang dibutuhkan untuk memahami Aljabar Linier, mata kuliah ini bukanlah suatu hambatan.

Hal ini dapat dibuktikan dengan nilai rata-rata mahasiswa yang berorientasi tujuan penguasaan sebesar 83,1 dan ratarata mahasiswa dengan orientasi tujuan performansi sebesar 80,7. Nilai rata-rata tersebut tergolong tinggi dan sekaligus memberikan gambaran bahwa orientasi tujuan ataupun orientasi penguasaan memiliki peranan dalam meningkatkan prestasi belajar mahasiswa pada materi Aljabar Linier. Wahyuningtyas (2013) memberikan kesimpulan dalam penelitiannya bahwa orientasi tujuan memiliki hubungan positif dengan semangat berprestasi mahasiswa, sehingga bisa dikatakan bahwa perbedaan orientasi akan membuat berbedanya semangat berprestasi mahasiswa.

Hasil angket menunjukkan bahwa semua mahasiswa Pendidikan Matematika memiliki dua orientasi tujuan sekaligus. Akan tetapi dalam penelitian ini dipisahkan berdasarkan kecondongan orientasi dari nilai angket yang diperoleh. Hal ini sebagaimana yang dipaparkan oleh (Barron \& Harackiewicz dalam Poortvliet \& Darnon, 2010) seseorang seringkali memiliki dua orientasi tujuan sekaligus yang berjalan bersamaan antara orientasi penguasaan dan performansi.

Orientasi tujuan performansi yang juga dimiliki pada mahasiswa Pendidikan Matematika dapat menyebabkan pola pembentukan persepsi penyebab yang tidak adaptif sehingga banyak mahasiswa kurang berupaya dalam mengejar keberhasilan dan pada umumnya merasa cukup dengan hasil yang diperolehnya. Hal ini dikarenakan fokus orientasi tujuan performansi adalah pada nilai baik dan pengakuan sosial tetang kompetensi yang dimilikinya.

Akan tetapi perlu menjadi perhatian bahwa orientasi tujuan performansi dalam kasus tertentu mempunyai korelasi yang positif dengan prestasi. Dierendonck dan Gaast (2013) menemukan bahwa orientasi tujuan performansi berpengaruh terhadap 
individu dengan kompetensi akademik ratarata rendah. Dalam hal ini, orientasi tujuan performansi memiliki pengaruh sebagaimana orientasi tujuan penguasaan. Definisi sukses subyektif yang cenderung membandingkan capaiannya dengan capaian orang lain tentu mampu mendatangkan dampak positif yang membuatnya berusaha untuk mencapai kompetensi akademik dari orang yang lebih baik darinya.

Adapun pada orientasi tujuan penguasaan akan mementingkan bagaimana cara atau usahanya agar dapat memahami dan menguasai materi (Puspitasari, et. al. 2013). Mahasiswa dengan orientasi penguasaan dapat dibantu dalam belajar dengan umpan balik yang berkelanjutan (Geitz, G., et al. 2015). Sehingga pemberian tugas atau latihan sebagai umpan balik secara teratur dan berkesinambungan mampu meningkatkan kemampuan penguasaan pada mahasiswa dengan orientasi tujuan penguasaan.

Wahyuningtyas (2013) menjelaskan suatu kondisi yang berbeda dari hubungan antara orientasi tujuan dengan prestasi. Menurutnya, dalam beberapa penelitian menunjukkan bahwa orientasi tujuan memiliki korelasi positif dengan prestasi. Namun ada pula penelitian yang berkesimpulan bahwa orientasi tujuan tidak berpengaruh secara signifikan terhadap prestasi ataupun motivasi. Dalam hal ini, hubungan antara orientasi tujuan dan prestasi memiliki perbedaan secara penelitian dan teori.

Pada penelitian ini, terdapat beberapa hal yang menjadi catatan dan temuan yang diasumsikan bisa berpengaruh terhadap kesimpulan bahwa tidak terdapatnya perbedaan prestasi belajar mahasiswa pada mata kuliah Aljabar Linier ditinjau dari orientasi tujuan, diantaranya:

a. Klasifikasi orientasi tujuan

Klasifikasi orientasi tujuan yang digunakan dalam penelitian ini adalah hanya menggunakan angket. Penggunaan angket sebagai instrumen tunggal untuk mengidentifikasi orientasi tujuan mahasiswa terkesan tidak valid. Hal ini dikarenakan angket tidak bisa menggali secara mendalam tentang kondisi yang sebenarnya mengingat angket yang digunakan hanya angket yang bersifat tertutup. Sehingga mahasiswa hanya memilih satu dari empat argumen (Sangat Setuju, Setuju, Tidak Setuju, Sangat Tidak Setuju) yang disediakan terhadap satu pernyataan.

Pemilihan angket sebagai instrumen tunggal klasifikasi orientasi tujuan adalah karena subjek penelitiannya adalah mahasiswa yang diasumsikan memiliki daya pikir logis dan kritis serta memiliki pehaman mendalam terhadap diri sendiri. Pengisian angketpun dilakukan dengan pendampingan untuk menghindari multitafsir dari pernyataan-pernyataan yang terdapat di dalam angket.

Oleh karena itu diharapkan pada penelitian selanjutnya, klasifikasi orientasi tujuan dapat dilakukan dengan angket, wawancara dan pengamatan.

b. Multi-orientasi dalam satu pribadi

Hasil temuan angket menunjukkan bahwa semua mahasiswa memiliki dua orientasi tujuan sekaligus. Temuan ini juga diperkuat oleh Barron \& Harackiewicz (dalam Poortvliet \& Darnon, 2010). Darnon (dalam Poortvliet \& Darnon, 2010) juga menyatakan bahwa orientasi tujuan penguasaan dapat diprediksi dalam suatu perbandingan sosial jika dikaitkan langsung dengan orientasi tujuan performansi.

Orientasi tujuan baik penguasaan ataupun performansi tetap akan dimiliki oleh setiap mahasiswa selama masih memiliki tujuan dan konsep diri. Adapun keberadaan multi-orientasi tujuan di dalam diri mahasiswa akan berpengaruh terhadap cara pandang mahasiswa terhadap cara pencapaian tujuan.

c. Mengukur Prestasi melalui Hasil Tes Individual

Salah satu yang menjadi catatan peneliti dalam penelitian ini adalah penggunaan tes mata kuliah Aljabar Linier sebagai kategorisasi prestasi belajar mahasiswa. Peneliti mengkhawatirkan 
instrumen tes Aljabar Linier tidak bisa untuk mengukur prestasi belajar yang diinginkan. Alasan serupa juga disampaikan Gul dan Shehzad (2012) yang menyatakan bahwa penggunaan hasil tes (IPK) untuk mengukur prestasi belajar yang meskipun membrikan informasi tentang keberhasilan akademik tetapi bisa jadi itu bukanlah alat ukur hasil pembelajaran yang sebenarnya.

Dalam suatu kondisi ideal, tentu penggunaan instrumen ini tidaklah menjadi masalah. Akan tetapi jika dalam tes mahasiswa dapat bekerjasama atau saling memberikan jawaban selama tes berlangsung, tentu ini akan mempengaruhi rataan nilai Aljabar Linier yang dijadikan sebagai alat ukur prestasi belajar mahasiswa. Dan akan mempengaruhi kesimpulan penelitian.

Terlepas dari ada atau tidaknya kerjasama antar mahasiswa selama pengumpulan data, ke depannya pengukuran prestasi berdasarkan orientasi tujuan bisa juga dilakukan dalam lingkup kelompok atau kelas. Hal ini dikarenakan prestasi sangat berkaitan erat dengan konteks sosial sehingga satu individu sering bergantung pada teman atau rekan kerja (Poortvliet \& Darnon, 2010).

Hannah, et al. ( 2011) juga menemukan bahwa orientasi tujuan dapat dikelompokkan dalam klaster-klaster yang dihubungkan melalui teori belajar mengajar, siswa dan matematika. orientasi tujuan dapat pula diklusterisasi melalui hubungan-hubungan lain selain itu.

\section{KESIMPULAN}

Konsep diri mahasiswa selama kuliah memberikan pengaruh terhadap motivasi belajar mahasiswa. Perbedaan pandangan mahasiswa dalam persepsi belajar memberikan pengaruh positif terhadap prestasi belajar pada setiap mata kuliah. Mahasiswa yang memiliki orientasi tujuan penguasaan memiliki pandangan yang positif tentang belajar. Mahasiswa yang memiliki orientasi tujuan performansi memandang belajar sebagai suatu proses yang tidak terlalu menentukan.

Hasil angket menunjukkan bahwa semua mahasiswa Pendidikan Matematika memiliki dua orientasi tujuan sekaligus. Akan tetapi mahasiswa yang condong kepada orientasi tujuan penguasaan sebanyak 8 orang, sedangkan mahasiswa yang condong pada orientasi performansi sebanyak 11 orang. Uji statistik deskriptif memberikan informasi bahwa rata-rata prestasi belajar mahasiswa dengan orientasi tujuan penguasaan adalah 83,1. Adapun rata-rata prestasi belajar mahasiswa dengan orientasi tujuan performansi adalah 80,7.

Hasil uji beda rata-rata prestasi belajar mahasiswa yang berorientasi penguasaan dan mahasiswa yang berorientasi performansi dengan menggunakan uji $\mathrm{t}-$ pihak kanan memberikan hasil $t_{\text {hitung }}=0,280364<$ $t_{\text {tabel }}=1,740$ yang artinya $\mathrm{H}_{0}$ diterima sehingga bisa disimpulkan bahwa tidak terdapat perbedaan yang signifikan prestasi belajar antara mahasiswa yang berorientasi tujuan penguasan dengan mahasiswa yang berorientasi performansi.

\section{DAFTAR PUSTAKA}

Alraggad, F., Ameert, O.A., \& AlSabaelah, A.M. 2014. Investigation the Relationship between Goal Orientation and Self Regulated Learning among Sample Jordanian University Students. Journal of Education and Practice, 5(39): 1-8.

Chen, W. W. \& Wong, Y. 2014. Chinese mindset: theories of intelligence, goal orientation and academic achievement in Hong Kong students. Educational Psychology: 1-12.

Dierendonck, D. \& Gaast, E. 2013. Goal Orientation, Academic Competences and Early Career Success. Emerald Insight, 18(7): $694-711$. 
Djaramah, S.B. 2012. Prestasi Belajar dan Kompetensi Guru. Surabaya: Usaha Nasional.

Ferryansyah, Widyawati, E., \& Rahayu, S.W. 2018. The analysis of students' difficulty in learning linear algebra. Journal of Physics, 1028: 1-6.

Geitz, G., Brinke D.J., \& Kirschner, P. 2015. Goal Orientation, Deep Learning, and Sustainable Feedback in Higher Business Education. Journal of Teaching in International Business, 26: 273-292.

Gul, F. \& Shehzad S. 2012. Relationship between Metacognition, Goal Orientation and Academic Achievement. Procedia - Social and Behavioral Sciences, 47: 1864 1868.

Hadi, YP. \& Budiningsih, TE. 2014. Konsep Diri Akademik Mahasiswa Penerima Beasiswa Bidik Misi Jurusan Psikologi Universitas Negeri Semarang. Educational Psychology Journal, 3(1): 26-31.

Hannah, J., Stewart, S., \& Thomas M. 2011. Analysing lecturer practice: the role of orientations and goals. International Journal of Mathematical Education in Science and Technology, 42(7): 975-984.

Indrawati, F. 2013. Pengaruh Kemampuan Numerik dan Cara Belajar terhadap Prestasi Belajar Matematika. Jurnal Formatif, 3(3): 215-223.

Keys, T. D., Conley, A. M., Duncan, G. J., \& Domina, T. 2012. The Role of Goal Orietations for Adolescent Mathematics Achievment. Contemporary Educational Psychology, 37: 47 - 54.

Ormrod, Jeanne Ellis. 2008. Psikologi Pendidikan Membantu Siswa Tumbuh dan Berkembang edisi keenan jilid 2. Terjemahan oleh Amitya K. 2009. Jakarta: Erlangga.

Poortvliet, P.M. \& Darnon, C. 2010. Toward a More Social Understanding of Achievement Goals: The Interpersonal Effects of Mastery and Performance Goals. Current Directions in Psychological Science, 19: 324-328.

Puspitasari, A., Purwanto, E. \& Noviyani, DI. 2013. Self Regulated Learning Ditinjau dari Orientasi Tujuan. Educational Psychology Journal, 2(1): 1-6.

Supardi. 2013. Aplikasi Statistika dalam Penelitian. Jakarta: Change Pulication.

Ulfah, N. \& Listiara A. 2017. Hubungan Orientasi Penguasaan dan Berpikir positif dengan Efikasi Diri Akademik dalam Pelajaran Matematika pada Siswa SMA. Jurnal Empati, 6(1): 276-281.

Variansyah, V. \& Listiara A. 2017. Hubungan Orientasi Tujuan Performa dengan Kecemasan Akademik pada Siswa Kelas X di Sma Negeri "A" Semarang. Jurnal Empati, 6(1): 419-424.

Wahyuningtyas, IV. 2013. Hubungan Motivasi Tujuan dengan Motivasi Berpestasi pada Mahasiswa. Educational Psychology Journal, 2(1): 22-29. 